\section{Transformations Involving 6-Ring Transitional Intermediates}

The importance of non-bonded interactions in the transition state of transformations involving substituted 1,2-ethanolamines has been extensively demonstrated ${ }^{1}$.

Recently StÜHMER and FrEY ${ }^{2}$ have applied these considerations in the assignment of configuration to the isomeric 1,3-diphenyl-3-amino 1-propanols. These authors observed that only the $\beta$-isomer in the form of its $\mathrm{N}$-acetyl derivative undergoes $\mathrm{N} \rightarrow \mathrm{O}$ acyl migration under acidic conditions whereas the $\alpha$-isomer on successive treatment with phosphorous pentachloride and water is converted irreversibly to the $\beta$-isomer ${ }^{3}$. On the basis of these observations and in analogy with the established specificity of these transformations in the case of the nor-ephedrines and the 1,2-diphenyl-ethanolamines (l.c.), the $\alpha$-isomer was assigned the erythro (mesoid) and the $\beta$-isomer the threo (racemoid) configuration.

A consideration of the probable transitional intermediates arising in the transformations of 1,3-propanolamine systems suggests the opposite configurational assignment from that proposed by STÜHMER and FREY. Thus, in contrast to the 5 -membered ring transitional intermediates formed in the reactions of 1,2-ethanolamines, the corresponding intermediates arising from the internal transformations of 1,3-propanolamines should be 6 -ring in character and consequently subject to steric factors encountered in cyclohexane derivatives". Considered from this point of view, the $\beta$-isomer of 1,3 diphenyl-3-amino-1-propanol should posses the erythro (mesoid) configuration (I) since the chair form of the 6-ring transition state for acyl migration bears the phenyl groups di-equatorially disposed in contrast to a polar-equatorial arrangement of these same groups required by the $\alpha$-isomer. The irreversible conversion of

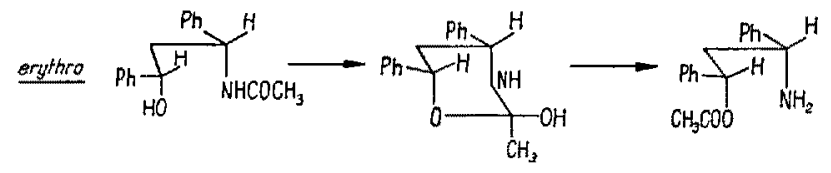

I

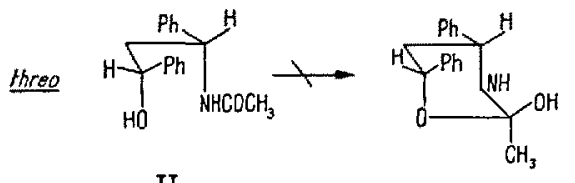

II

the $\alpha$-isomer $\rightarrow \beta$-isomer should correspondingly require the formation, with inversion at $\mathrm{C}-\mathrm{OH}$, of a 6-ring oxazine as a transitional intermediate. The oxazine derived from the eyythro-form (I) could exist in two

1 P. I. Pollak and D. Y. CuRtin, J. Amer. Chem. Soc. 72, 961 (1950). - L. H. WeLSH, ibid. 71,3500 (1949). - V. BRUCKNer, G. Fonor, J. KIss, and J. Kovacs, J. Chem. Soc. 1948, 885. - J. Artenaurrow, D. F. Elliot, and G. F. Penny, J. Chem. Soc. 1948, 310.-J. Weijlard, K. Pfister 3rd, E. F. Swanezy, C. A. Robinson, and M. Trshler, J. Amer. Chem. Soc. 73, 1216 (1951).

2 W. Srohmer and H. FreY, Arch. Pharm. $286 / 58,8,26$ (1953).

W. Stuhmer and W. Heinrich, Chem. Ber. 84,224 (1951).

4 D. H. R. Barton, Exper. 6, 315 (1950). possible conformations, III $a$ and III $b$, both of which possess unfavorable phenyl-hydrogen interactions.
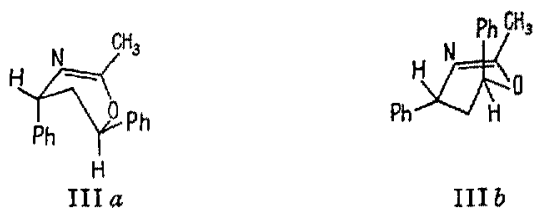

III $b$

The oxazine derived from the thyeo form (II), however, can give rise to either an unfavorable conformation IVa having phenyl-phenyl interaction or a second conformation IVb in which all nonbonded interactions are minimized.
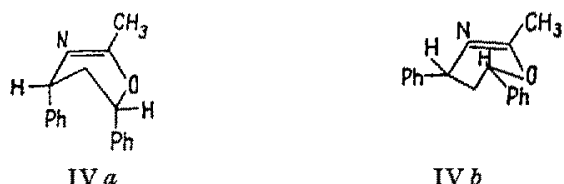

These same considerations likewise provide a satisfactory explanation for the selective formation of a tribenzoyl derivative with the erythro-form of 1,3-dihydroxy-2-aminoöctadecane in contrast to the threo-form which only gives a dibenzoyl derivative as recently reported ${ }^{1}$. Only in the case of the erythro isomer could an initially formed $\mathrm{N}, \mathrm{O}_{1}$-dibenzoyl derivative give rise to a 6-ring transitional intermediate favorable to $\mathrm{O}_{1} \rightarrow \mathrm{O}_{3}$ acyl migration.

N. L. WENDLER

Merck \& Co., Inc., Rahway, New Jersey,June 16, 1953.

\section{Zusammenfassung}

Dem $\beta$-Isomer des 1, 3-Diphenyl-3-amino-1-propanols, welches in der Literatur als Threo-Verbindung formuliert ist, wird die mesoide Erythro-Konfiguration zugewiesen. Diese Zuweisung erfolgt auf Grund der vorauszusehenden grösseren Stabilität des bei der $\mathrm{N} \rightarrow \mathrm{O}-\mathrm{Azyl}$ wanderung intermediär anftretenden 6-gliedrigen Ringes.

Die einseitige Umwandlung des $\alpha$-Isomers des $1,3-\mathrm{Di}-$ phenyl-3-amino-1-propanols in die $\beta$-Form durch Phosphorpentachlorid und nachfolgende Hydrolyse wird durch die günstigere Konformation des aus der ThreoForm erhältlichen Oxazins erklärt.

1 H. E. Carter, D. Shapiro, and J. B. Harrison, J. Amer. Chem. Soc. 75, 1007 (1953).

\section{Diabetogene Wirkung des 2,3,4-Triketo- Tetrahydropyridins}

Im Rahmen unserer Arbeiten über Polyoxoverbindungen prüften wir die diabetogene Wirkung von Osts Pyromekazon ${ }^{1}$, das nach den Untersuchungen von Peratoner ${ }^{2}$ die Struktur des 2,3,4-Triketo-tetrahydro-

1 H. Ost, J. pr. [2] $23,442(1881) ; 27,260$ (1883).

2 A. PERATONER, R. A. L. [5] 11, I., 339 (1902); G. 41, II., 628, 660 (1911). 